\title{
The Selection of Journal and Submission Process During Preparation of Scientific Articles
}

\author{
Makale Yazımında Dergi Seçimi ve Dergiye Gönderme Süreci
}

\section{Hakan Yaman}

\begin{abstract}
Science is based on sharing of ideational, observatory, and professional experiences among scientists. Their professional communication is performed by presentations and discussions at scientific meetings and publications in peer-reviewed journals. Even after successful research the sharing of their findings is causing challenges. This review tries to guide new beginning colleagues in their research activities. Even the preparation of publication calls out for patience and persistence, the publication of our scientific work will help to bring our family medicine to an international niveau.
\end{abstract}

Key words: Publications, research, family practice

\section{ÖZET}

Bilim, bilim insanlarının kendi aralarında yapmış oldukları fikirsel, gözlemsel ya da mesleki deneyim paylaşımlarına dayanmaktadır. Mesleki iletişimleri ise, bilimsel toplantılarda yapmış oldukları sunumlar, tartışmalar ya da hakemli dergilerde yayınlamış oldukları yayınlar vesilesiyle olmaktadır. Yapılan araştırma başarı ile sonuçlanmasına rağmen, elde edilen bulguların bilim çevreleri ile paylaşım aşamasında sıkıntılar yaşanmaktadır. Bu derleme ile yayın faaliyetlerine yeni başlayan meslektaşlarımıza yol gösterilmek istenmiştir. Eserlerin yayınlanacak hale getirilmeleri, sabır ve sebat gerektirmektedir. Bilimsel çalışmalarımızın sonuçlarını yayınlayabilmek, ülkemizdeki aile hekimliği disiplininin eğitim ve uygulama alanında uluslararası bilimsel standartları yakalamasına yardımcı olacaktır.

Anahtar kelimeler: Yayınlar, araştırma, aile hekimliği

Received / Geliş tarihi: 28.03.2017, Accepted / Kabul tarihi: 20.06.2017

*Address for Correspondence / Yazışma Adresi: Hakan Yaman, Uncalı Mh. 1262. Sk. No: 15 A Blok Kat: 2 Daire: 5 Öksüzoğlu Konakları 07000 KonyaaltıAntalya-TÜRKIYE Tel: 05363209933 E-mail: hakanyam@yahoo.com

Yaman H. The Selection of Journal and Submission Process During Preparation of Scientific Articles. TJFMPC, 2017;11(3): 194-201.

DOI: $10.21763 /$ tjfmpc.336159 


\section{GíRIŞ̧}

Bilim, büyük oranda bilim adamları arasında yapılan fikir, gözlem ve deneyim alışverişine ve mesleki tartışmalara dayanmaktadır. Kendi aralarındaki mesleki iletişimleri ise, genellikle kongrelerde yapılan sunumlar ve verilen konferanslar ya da hakemli dergilerde yayınlanan makaleler aracılığıyla olmaktadır. ${ }^{1}$

Bilimsel iletişimde, bilimsel paylaşımların rolleri çok önemli bir konuma sahip olsalar da, kongrelerde sunulan bildirilerin az kısmı hakemli dergilerde makale olarak yayınlanmaktadırlar. ${ }^{2}$

Halbuki bu ilginç bir paradokstur, çünkü akademiyada çalışan birçok bilim adamından farklı nedenlerden dolayı (örn. Akademik yükseltme, atanma, bilimsel performans vb) yayın hazırlama ve dergilerde yayınlama beklentisi bulunmaktadır. ${ }^{1}$

Yapılan araştırmaların neden dergilerde yayınlanmadığına ilişkin birçok neden(sebep) ileri sürülebilse de en önemlisi, araştırma verilerini makaleye dönüştürme sürecinde sıkıntıların yaşanıyor olmasıdır (örn. Deneyimsizlik, zaman yetersizliği, ekip çalışmasının olmaması, iş yükünün fazlalığı vb.).

Bu derlemede aşama, aşama okurlara makale hazırlandıktan sonra (makaleye ilişkin bazı öğeler ve özellikler hatırlatıldıktan sonra) dergi seçim ve yayına gönderme süreci açıklanacaktır.

\section{Derginin Seçimi}

Akademik ortamda çalışan bilim insanları, mesleki hayatları boyunca pek çok kez eserlerini dergilere göndermişlerdir. Dergideki hakemlik süreci ve derginin kendi işleyiş süresinden kaynaklanan nedenlerden dolayı, bir makalenin bir dergi tarafından değerlendirilmesinin aylar sürmesi olasıdır. Değerlendirmelerin her zaman müspet sonuçlanmaları da mümkün olmamaktadır. Bu nedenle eserin gönderileceği dergi özenle seçilmelidir. $^{3}$

Eserin gönderileceği dergi nihai olarak seçilmeden önce; eserin gönderilebileceği potansiyel bir dergi listesi hazırlamak uygun olacaktır. Listeyi hazırlamak için farklı yollar izlenmesi mümkündür. Birisi, belki de en sık kullanılanı, makaleyi yazım aşamasında kullanılan referanslar arasından olası dergilerin seçimidir. $\mathrm{Bu}$ dergilerin editörlerinin eserinize daha fazla ilgi duymaları olasıdır. Bunun dışında, bazı dergi dizinlerinden de yararlanmak mümkündür. Ancak, öncelikle eserinizi ne tür bir dergide yayınlamak istediğiniz konusunda karar verilmelidir. ${ }^{3,4}$

\section{Bilimsel Derginin Özellikleri}

Bilimsel dergilerin seçiminde önem arz edebilecek bazı özellikler bulunmaktadır. Dergi seçerken bunların dikkate alınması, potansiyel yazarların hedeflerine daha isabetli ulaşmalarını kolaylaştıracaktır. ${ }^{1,3-5}$

Bilimsel dergilerin özelliklerine ilişkin döküm tablo 1'de gösterilmiştir.

\section{Dergiye Makale Göndermeden Önce Dikkate Alınması Gereken Olasılıklar}

Yukarıda sayılan etmenler dikkate alındıklarında, aşağıdaki olasılıklar karşımıza çıkabilir: ${ }^{3}$

1. Gözü kapalı gönder: Gözü kapalı olarak makalenizi göndereceğiniz olasılıktır. Yüksek etkisi olan bir dergide, yayınlama olasılığ yüksek olan tercihtir. Bu olasılığı oluşturan etmenlerin özellikleri ise şunlardır; derginin daha önce çalışma alanınıza benzer konulu makaleleri yayınlamış olması, makalelerin metodolojilerinin sizin makalenize benzer olması, eserinizin derginin hedefleriyle uyumlu olması, dergi okurlarının ilgili alanına giriyor olması ve yazarlara bilgi direktifleri ve editörlerin beklentilerine uygun hareket edilmiş olması. Derginin saygınlığının, yazarın beklentilerine uygun olduğu anlaşılmaktadır. Yayınlanan makale yazarın kariyer gelişimine önemli katkıda bulunacaktır. Derginin takvimi yazarın takvimi ile uyum içindedir.

2. Kumar oynamak olur: Yüksek etki faktörü olan dergide, kabul edilme şansı daha düşüktür. Dergide benzeri makaleler bulunmamaktadır, metodolojileri farklıdır ve eseriniz derginin yazım kurallarına ve editörün beklentilerine uygun değildir.

3. Göndersen de olur, göndermesen de olur: Derginin kabul etme olasılığı yüksek olmasına rağmen, derginin etkisi düşüktür. Derginin çok fazla saygınlığı bulunmamaktadır, hatta atama jürileri ve diğer kurumlar nezdinde pek itibarı bulunmamaktadır. Dergiye gönderme, yayınlanma zamanı ve yazarın takvimi arasında uyum bulunmamaktadir.

4. Olmasa da olur: Makalenin, düşük etkili bir dergi tarafından kabul edilme olasılığı da bulunmamaktadır. Derginin değerlendirme ve yayınlama süreleri ile yazarın takvimi arasında uyumsuzluğun bulunması, eserin konusunun düşük etkili derginin yönelimi ile uyuşmaması ve red edilme olasılığının yükssek olduğu durumdur. 


\begin{tabular}{|c|c|}
\hline $\begin{array}{l}\text { Derginin } \\
\text { ozzellikleri }\end{array}$ & Açıklamalar \\
\hline $\begin{array}{l}\text { Kapsamı ve } \\
\text { amacı }\end{array}$ & $\begin{array}{l}\text { Eserinizin arzu ettiğiniz okur kesimi ve bilimsel topluluğa ulaşıp ulaşmayacağı konusunda } \\
\text { fikir vermektedir. Uluslararası bir etki yaratılmak isteniyorsa, yabancı dilde yayın yapan } \\
\text { ve yaygın bir okur kitlesine ulaşan, belki de genel yayın yapan bir dergi seçilmelidir. Elde } \\
\text { ettiğiniz bulgular ve buradan çıarsadığınız sonuçlar doğrultusunda dergi listenizi } \\
\text { daraltmanı mümkün olacaktır. }\end{array}$ \\
\hline $\begin{array}{l}\text { Derginin } \\
\text { saygınlığ }\end{array}$ & 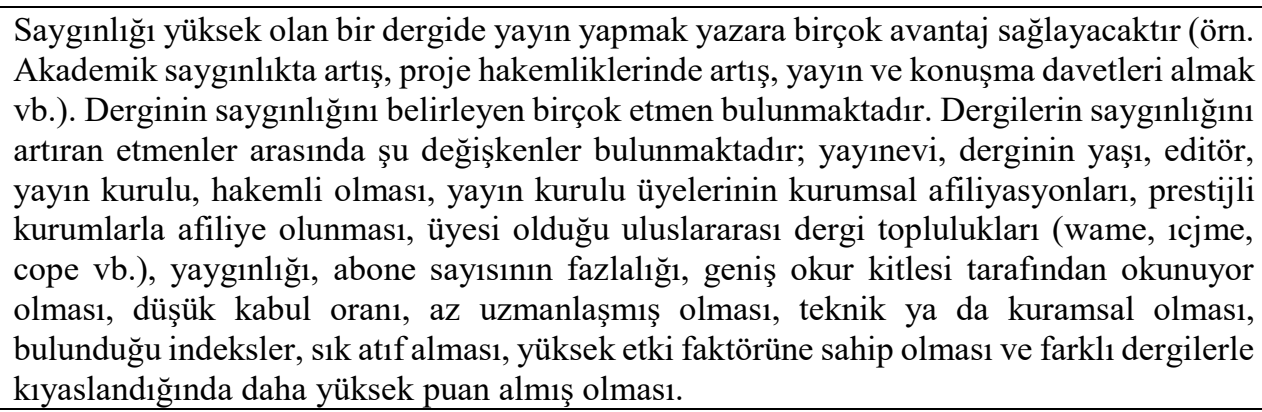 \\
\hline $\begin{array}{l}\text { Derginin } \\
\text { görünürrlüğü ve } \\
\text { etkisi }\end{array}$ & $\begin{array}{l}\text { İnternet öncesi dönemlerde, dergilerin görünürlükleri abone sayısı ile ölçülmekteydi. } \\
\text { Günümüzde ise görünürlükleri, dergi özetlerinin tarandığ dizinlerin/indekslerin niteliği } \\
\text { ve sayısı ile ölçülmektedir. Dergilerin ayrıca etkisini değerlendiren farklı bibliyometrik } \\
\text { veriler de bulunmaktadır. Yazarlar, günümüzde eserlerinin ve düşüncelerinin global } \\
\text { ölçekte yayıllmalarını önemsenmektedir. Bu çerçevede elektronik ve erişim ücretsiz yayın } \\
\text { yapan dergiler tercih edilmektedir. İlginç bir biçimde, bu dergilerin genelde daha fazla atıf } \\
\text { aldıkları görülmüştür. }\end{array}$ \\
\hline $\begin{array}{l}\text { Derginin etki } \\
\text { faktörü }\end{array}$ & $\begin{array}{l}\text { Bilimsel dergilerin, bilimsel etkilerini ölçmek maksadıyla farklı bibliyometrik ölçüler } \\
\text { bulunmaktadır. Dergilerin göreceli nitelikleri bu ölçülere göre yapılmaktadır ve dergilerin } \\
\text { buna göre kendi içlerinde sıralamaları bulunmaktadır. Bunun için 1s1 journal citation } \\
\text { reports, scımag, scopus journal analyzer gibi farklı dizin ve web siteleri mevcuttur. }\end{array}$ \\
\hline $\begin{array}{l}\text { Derginin } \\
\text { tarandığı } \\
\text { indeksler }\end{array}$ & $\begin{array}{l}\text { Ülkemizde, akademik yükseltmelerde 1S1 web of science dizinlerinde yer alan dergiler } \\
\text { öncelikle tercih edilmektedir. Dergi listenizde bu dizinde bulunan dergilere } \\
\text { (scientific.thomsonreuters.com/products/jcr/) yer verilmelidir. Bu dizinde olmayıp da, } \\
\text { uluslararası ölçekte yayın yapan dergiler düşünülüyor ise, directory of open access } \\
\text { journals (www.doaj.org) ya da free medical journals } \\
\text { (http://www.freemedicaljournals.com/) gibi ücretsiz dizinler aracillğıly dergilerin web } \\
\text { sitelerine ulaşmak mümkün olacaktır. Ulusal ölçekte bir dergi tercih edilecek olursa (ki } \\
\text { bunu hararetle öneririz), ulakbim'in tr dizin'de (http://cabim.ulakbim.gov.tr/tr-dizin/tr- } \\
\text { dizinde-dizinlenen-dergi-listesi/ ) taranan dergilere bakılmalıdır. Bunun haricinde, } \\
\text { camianızın yayınlamış olduğu dergiler ya da arkadaşlarınızın/meslektaşlarınızın } \\
\text { önerdikleri dergiler de seçenekler arasında bulunacaktır. }\end{array}$ \\
\hline $\begin{array}{l}\text { Derginin kabul } \\
\text { olasılığı }\end{array}$ & $\begin{array}{l}\text { Dergi seçiminde en önemli noktalardan birisi seçilen derginin kabul olasılığıdır. Bazı aşırı } \\
\text { rağbet gören dergilerin kabul oranları \%10'lara kadar düşmektedir. } \\
\text { Reddetme olasılı̆̆ } \text { yüksek olan dergiye gönderilen makale, dergiye uygun olmadığ } 1 \\
\text { takdirde uzun bir bekleyişten sonra red yazısı alma olasılığı yüksektir. } \\
\text { Derginin kabul olasılığını artıran diğer bir unsur ise, dergi yazım kurallarına ve üslubuna } \\
\text { uyumun olmasıdır. Derginin eski makalelerine benzeşim olması şansı artırmaktadır. } \\
\text { Ancak makalenize benzer bir eserin yakın zamanda yayınlanmış olması kabul edilme } \\
\text { olasıllığınızı azaltacaktır. Bazı dergilerin, sıkı bir metodoloji ve istatistik analiz beklentisi, } \\
\text { ya da makalenizin aşırı uzun olması kabul edilme olasılığını azaltacaktır. }\end{array}$ \\
\hline Hakemli olması & $\begin{array}{l}\text { Akademik ortamda, hakemli dergilerde yayın yapmanın kıymeti daha fazladır. Hakemli } \\
\text { dergiye ilişkin tanımlama ise üniversitelerarası kurul tarafından şöyle yapılmıştır: "editörü } \\
\text { ve en az beş değişik üniversitenin öğretim üyelerinden oluşmuş danışmanlar grubu olan, } \\
\text { bilimsel/sanatsal özgün araştırma makaleleri yayınlayan, yılda en az iki kez yayınlanan ve } \\
\text { son beş yılda düzenli olarak basılıp dağıtımı yapılmış, üniversite kütüphanelerinde } \\
\text { erişilebilir olan dergi."** derginin hakemli olması bilimsel içeriğinin ve ilgili alanının } \\
\text { mesleki standardının ilgili alanın uzmanları tarafından denetlendiği anlamına gelmektedir. }\end{array}$ \\
\hline
\end{tabular}




\begin{tabular}{|c|c|}
\hline $\begin{array}{l}\text { Hakemlik } \\
\text { süresinin } \\
\text { uzunluğu }\end{array}$ & $\begin{array}{l}\text { Dergilerde, hakemlik süresinin uzun sürmesinin sakıncaları olmaktadır. Uzun sürdüğü } \\
\text { takdirde yazının güncelliği ve yazarın yayın takvimi olumsuz etkilenecektir. Bunu } \\
\text { önlemek için bilimsel dergiler birçok tedbir almaktadır (editoryal ofisin zamana dayalı } \\
\text { verim göstermeleri, hakem havuzunun geniş tutulması, hakemliğin ücretli yapılması, } \\
\text { derginin elektronik edisyonunun bulunmas, yazışmaların elektronik yapıllyor olmas, } \\
\text { derginin internette makale yükleme sitesinin bulunması vb.). Dergilerin web sitelerinde bu } \\
\text { konuyla ilgili bilgiler bulunabilmektedir (örn. Hakemlik süresi, eserin kabulünden } \\
\text { yayınına kadar geçen süre gibi). }\end{array}$ \\
\hline $\begin{array}{l}\text { Baskiya girme } \\
\text { süresi }\end{array}$ & $\begin{array}{l}\text { Makalenin kabulünden, baskıya girmesine kadar geçen zaman da önemlidir. Bazı basılı } \\
\text { dergiler teknik nedenlerle ve seyrek yayın aralıkları nedeniyle makaleyi kabul etseler dahi } \\
\text { yayınlayamamaktadırlar. Makalenin yayınlanması aylar hatta yıllar sürebilmektedir. Bu } \\
\text { da çalışmanızın bulgularının geç paylaşılacağı anlamına gelmektedir. Bazı dergiler, hem } \\
\text { elektronik, hem de kağıt baskı, bazıları ise sadece elektronik baskı yapmaktadırlar. } \\
\text { Makalenin acele yayınlanması gerektiği durumlarda, tercih elektronik ve sık aralıklarla } \\
\text { yayın yapan dergiler lehinde olmalıdır. }\end{array}$ \\
\hline $\begin{array}{ll}\text { Dergi } & \text { baskı } \\
\text { ücretleri } & \end{array}$ & $\begin{array}{l}\text { Bazı dergiler, ki sayıları giderek artmaktadır, baskı ve işlem ücreti adı altında ücretler talep } \\
\text { etmektedirler. Dergiler, s1klıkla reklam ya da hizmet ettikleri dernek ya da topluluğun bir } \\
\text { yayın organı olarak ilgili kurum ve şirketler tarafından desteklenmektedirler. Ancak bazı } \\
\text { dergilerin mali durumlarının yeterli olmaması, endüstri ile işbirliği yapmaması, abone } \\
\text { sayısının az olması ya da ücretsiz erişim hakkı tanıması nedeniyle ücret talep } \\
\text { etmektedirler. Ücretin talep ediliyor olması, gönderilen eserin hakemlik sürecini } \\
\text { etkilememekte ve ancak yazının kabulü sonucunda tahsil edilmektedir. Bazı dergiler ise } \\
\text { başvuru ücreti gibi iadesi olmayan ücretler de talep etmektedirler. }\end{array}$ \\
\hline
\end{tabular}

* ÜAK. Sosyal Bilimlerde Doçentlik atama kriterleri. Erişim: http://www.uak.gov.tr/temelalan/E_sosyal_180416.pdf. Erişim tarihi: 01.03.2017

\section{Eserin Belirlenen Dergiye Gönderilmek Üzere} Hazırlanması

Eserin gönderileceği dergi belirlendikten sonra, gönderilmeye hazır hale getirilmiş eserin son kez gözden geçirilmesi gerekmektedir. Dergi editörleri ve daha sonra atanan hakemler bir eseri değerlendirirken şu noktalara dikkat etmektedirler (Tablo 2): $:^{1,6}$

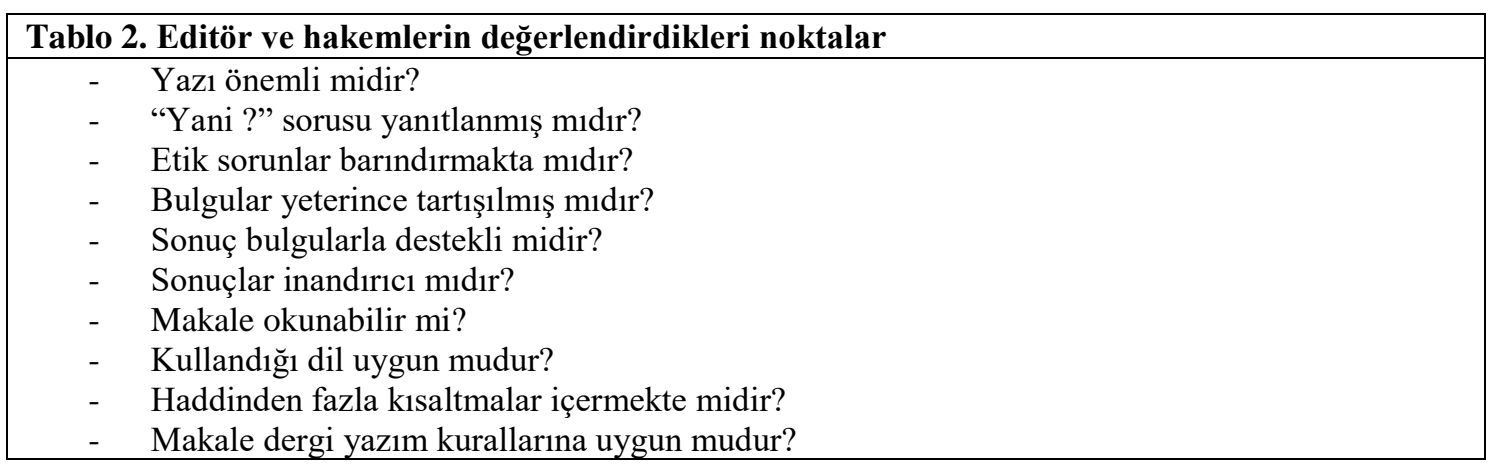

\section{Eserin Son Halinin Verilmesi}

$\mathrm{Bu}$ vesileyle, eseri son bir kez gözden geçirecek olursak, bir orijinal makalede aşağıda söz edilecek olan bölümlerin ve bölüm özelliklerinin bulunması beklenmektedir. Ancak, orijinal çalışma dışında başka türde bir eser olarak hazırlanan diğer eserlerin (derleme, teknik ilerleme makalesi, teknik rapor, veri tabanı makalesi, yazılım makalesi, tartışma, çalışma protokolü, olgu sunumu, editoryal, editöre mektup vb.) yazılış biçimleri farklıdır ve ilgili derginin yazım kuralları dikkate alınarak hazırlanmalıdır. $^{7}$
Hatta, orijinal makale ve sistematik gözden geçirme/derleme ve meta-analizlerin hazırlanmalarına rehberlik edecek farklı protokoller bulunmaktadır; randomize kontrollü çalışmalar için CONSORT, gözlemsel çalışmalar için STROBE, sistematik gözden geçirmeler ve meta-analizler için PRISMA ve tanısal çalışmalar için STARD kullanılır. Bunun için ayrıca "EQUATOR Network" ve NLM'nin "Research Reporting Guidelines and Initiatives"den yararlanmak mümkündür. ${ }^{8}$ Güçlü bir eser için, aşağıdaki sorunlardan kaçınmanın yararlı olduğu bildirilmektedir (Tablo 3). 


\begin{tabular}{|cl|}
\hline Tablo 3. Kaçınılması gereken noktalar-1 \\
\hline - & Literatürün yetersiz olması \\
- & Atıfların uygunsuzluğu \\
- & Anlaşılmaz giriş \\
- & Belirsiz araştırma sorusu \\
- & Yetersiz tarif edilmiş örneklem \\
- & Yetersiz metodoloji tarifi \\
- & İstatistiğin net olmaması \\
- & Uygun olmayan istatistik analizi \\
- & Tartışmanın yetersizliği \\
- & Yazım üslubun yetersizliği \\
- & Aşırı uzun olması \\
\hline
\end{tabular}

Diğer önemli nokta ise, makalenin dergi ile alakalı olmaması ve bilime yeterince katkısının olmamasıdır. Ancak, bir makalede olmazsa olmazlardan bazıları araştırma sorusu, hipotezin konsepti ve metodolojinin uygunluğudur. Buna ilaveten elde edilen sonuçların yeterince tartışılmış olması, bulguların daha önceki literatürle uyumlu olması, literatürün uluslararası ve varsa ulusal düzeyde olması ve çalışmanın dil kalitesi de önemlidir. ${ }^{9,10}$

Makale, son kez gözden geçirilirken aşağıdaki noktalara dikkat edilmesi gerekmektedir (Tablo 4): ${ }^{1}$

\section{Tablo 4. Dikkat edilmesi gereken noktalar-2}

- Metnin yazım kuralı denetiminden geçirilmiş olması

- Yazıların sola dayanarak yazılmış olması

- Özetteki rakamların, metnin içindekilerle uyumlu olması

- Materyal-metod kısmında tarif edilen yöntemlere uygun bulguların olması

- Yazar, makaleyi önce sesli biçimde kendi kendine okumalıdır. Makale okunurken akıcı mıdır? Kolay anlaşılabilir midir? Göze batan herhangi bir durum var mıdır?

- Makalenin albenisi nedir?

- Çalışma, amaç kısımında araştırma sorusunu karşılıyor olmalıdır.

- Makale kendi içinde bölümleriyle tutarlı olmalıdır.

- Sonuçlar veri ile desteklenmelidir.

- $\quad$ Özetteki sonuç, metindeki sonuç ile uyumlu olmalıdır.

Dergide, referansların yazım biçimi derginin yazım kurallarına göre belirlenmektedir. Örneğin, biyomedikal alanda birçok saygın dergi, Vancouver/ICMJE Style'1 kullaniyorken, sosyal bilimleri alanında ise daha çok APA Style tercih edilmektedir. Bunun dışında birçok başka yazım biçimi de bulunmaktadır (Tablo 5).

Makale ya da eser yazımında, kaynakların/referansların yönetimini kolaylaştırma amacıyla farklı yazılımlar geliştirilmiştir. Bunlardan en çok bilinen ve kullanılanları Tablo 6'da gösterilmiştir. Kimin yazar olacağının, projenin planlanma aşamasında görüşülüp bir karara bağlanması gerekmektedir. Yazının, son hali verilirken yazarlık hakkı ile ilgili noktalar dikkate alınmalıdır. Yazar olmanın asgari koşuları ise ICJME tarafından şu biçimde tanımlanmıştır: ${ }^{11}$
“1)Kavram ve tasarıma veya verilerin toplanmasına veya verilerin işlenmesi ve yorumunda dikkate değer katılım,

2) Makale taslağının olușturulması veya makalenin önemli kavramsal içeriğinin düzeltilmesi sürecine katılım,

3) Basılacak olan son sürümün onaylanmas1 ile yazarlığa hak kazanılmış olmalıdır. Yazarlar 1,2 ve 3' teki koşulları karşılamalıdır."

Bunun haricinde, bir yazar çalışmaya yaptığı katkı oranında sorumluluk taşıdığ 1 gibi, diğer yazarların çalışmaya katkıları konusunda haberdar olmalıdır. Diğer yazarların yaptıkları çalışmalar hususunda güven duymalıdır. Yazarlar tüm kriterleri yerine getirmelidirler. $\mathrm{Bu}$ kriterleri yerine getirmeyen, ancak çalışmaya katkısı olan kişilerin isimlerine bilgi notu kısmında yer verilmelidir. ${ }^{12}$ 


\begin{tabular}{|c|c|}
\hline Yazım Biçimi & Örnek \\
\hline Pubmed Style & $\begin{array}{l}\text { Yaman H, Vural R. Yaşlı Bireylerde Sarkopeninin Yönetimi. TJFMPC 2016;10(4): 243-249. } \\
\text { doi: 10.21763/tjfmpc.271330 }\end{array}$ \\
\hline Web Style & 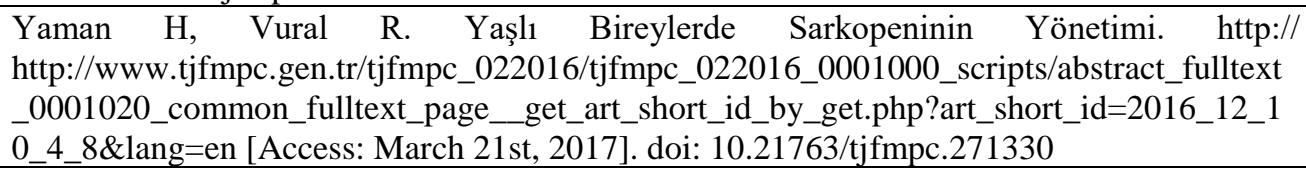 \\
\hline AMA Style & $\begin{array}{l}\text { Yaman H, Vural R. Yaşl1 Bireylerde Sarkopeninin Yönetimi. TJFMPC. 2016;10(4): 243-249. } \\
\text { doi: } 10.21763 / \mathrm{tjfmpc} 271330\end{array}$ \\
\hline $\begin{array}{l}\text { Vancouver/ } \\
\text { ICMJE Style }\end{array}$ & $\begin{array}{l}\text { Yaman H, Vural R. Yaşlı Bireylerde Sarkopeninin Yönetimi. TJFMPC. (2016), [cited March } \\
21^{\text {st }}, 2017 \text { ];10(4): 243-249. doi: 10.21763/tjfmpc.271330 }\end{array}$ \\
\hline $\begin{array}{l}\text { Harvard } \\
\text { Style }\end{array}$ & $\begin{array}{l}\text { Yaman, H. \& Vural, R. (2016) Yaşlı Bireylerde Sarkopeninin Yönetimi. TJFMPC, 10(4), } \\
\text { 243-249. doi: 10.21763/tjfmpc.271330 }\end{array}$ \\
\hline $\begin{array}{l}\text { Turabian } \\
\text { Style }\end{array}$ & $\begin{array}{l}\text { HAKAN YAMAN, Ramazan Vural R. 2016. Yaşlı Bireylerde Sarkopeninin Yönetimi. } \\
\text { TJFMPC, 10(4), 243-249. doi: 10.21763/tjfmpc.271330 }\end{array}$ \\
\hline Chicago Style & $\begin{array}{l}\text { YAMAN, HAKAN, Ramazan Vural. "Yaşlı Bireylerde Sarkopeninin Yönetimi". TJFMPC } \\
10.4 \text { (2016), 243-249. doi: } 10.21763 / \text { tjfmpc.271330 }\end{array}$ \\
\hline MLA Style & $\begin{array}{l}\text { YAMAN, HAKAN, Ramazan Vural. Yaşlı Bireylerde Sarkopeninin Yönetimi. TJFMPC } 10.4 \\
\text { (2016), 243-249. Print. doi: } 10.21763 / \text { jffmpc. } 271330\end{array}$ \\
\hline APA Style & $\begin{array}{l}\text { YAMAN, H. \& Vural, R. (2016). Yaşlı Bireylerde Sarkopeninin Yönetimi. TJFMPC, 10(4), } \\
\text { 243-249. doi: 10.21763/tjfmpc.271330 }\end{array}$ \\
\hline
\end{tabular}

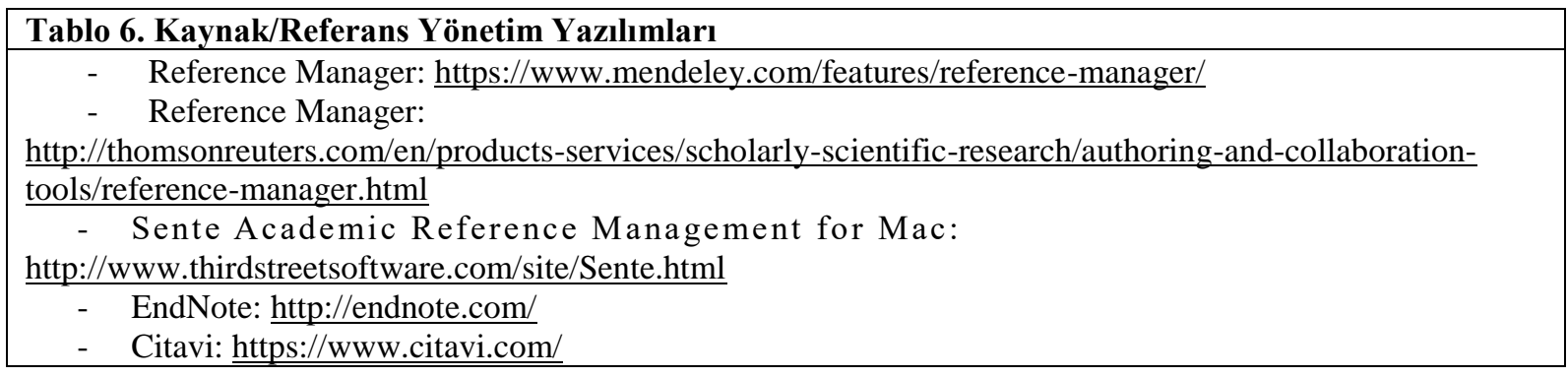

\section{Eserin Dergiye Gönderilmesi}

Eser dergiye gönderilirken, dergi yazım kuralları ile uyumluluğu gözden geçirilmelidir. Dergiye hitaben kapak ve takdim mektubu hazırlanmalıdır. Eserin, eş zamanlı başka bir dergiye gönderilmediği beyan edilmelidir. Yapılan çalışma ve taşıdığı özelliklerle ilgili editörle paylaşılmak istenilen konular belirtilmelidir. Talep ediliyorsa, tüm yazarların imzaladığı telif hakkı formu imzalanmalı ve gönderilecek olan esere eklenmelidir. Makalenin en son hali okunup, tüm yazarlar tarafindan onaylanmalıdır.

Dergilerin çoğunluğu, internet aracılı̆̆ıyla makale kabul etmektedir ve yazarlar da sıklıkla bu tarz dergileri tercih etmektedirler. Eseriniz dergiye ulaştığında önce bir editör atanmaktadır. Editör, eserin dergiye uygunluğu ve bilimsel yeterliliğini değerlendirmekte ve uygun görürse hakem atması yapmaktadır. En az iki hakem ataması yapılmaktadır. Açık erişim politikası olan dergiler, sıklıkla eseri gönderme aşamasında yazarlardan potansiyel hakem önerileri istemektedirler. Uygun görülürse bu hakemler arasından seçim yapılmaktadır. Hakemler, çıkar çatışmaları bulunmas1 durumunda hakemlik görevinden çekilmekte serbesttirler. Hakemlerin, makul sürede raporlarını yazmaları beklenmektedir. $\mathrm{Bu}$ süre ortalama iki haftadır ve özellikle hızlı editörlük süreci konusunda hassasiyet gösteren dergiler bu süreyi sağlamaya çalışmaktadırlar. En az iki hakem raporu tamamlandığında, eğer raporlar tatmin edici ise editör eser hakkında kararını açıklayacaktır. Saygınlığı yüksek, uluslararası dergiler genelde eserlerin olabildiğince kısa sürede değerlendirilmesi konusunda hassasiyet göstermektedirler.

Hakem raporlarına göre temelde üç farklı karar yazarlara bildirilmektedir; kabul, revizyon ya da red.

- Kabul: Çok nadiren, bir makale ilk turda olduğu gibi doğrudan kabul kararı alacaktır. Kabul genelde yapılan düzeltmelerden sonra editörlerin olumlu 
değerlendirmeleriyle olmaktadır.

- Revizyon: Farklı türde revizyon önerilerinde bulunulmaktadır. Bunlar minör revizyon, majör revizyon ve yeniden başvurmak üzere red. Minör revizyon haberi yazarları rahatlatır. Makalede yapılacak bazı küçük düzeltmelerle, makalenin kabul edilme ihtimalinin oldukça yüksek olduğu anlaşılmaktadır. Ancak hakemlerin önerileri ciddiye alınmalıdır ve öneriler harfiyen yerine getirilmelidir. Yapılan değişiklikler ayrı bir sayfaya not edilip, editöre ve dolayısıyla hakemlere gönderilecek olan yanita eklenmelidir.

- Red: Bazen dergideki hakemlik ve makalenin işlem süresini uzatmamak için, yeniden gönderilmek üzere makale reddedilebilir. Önerilen düzeltmelerin, çok fazla zaman alacağı kanaati bulunduğu için böyle bir karar alınmaktadır.

Kesin red ise sıklıkla karşılaşılan bir yanıttır. Bazen makalenin başka nereye gönderilebileceğine ilişkin önerilerde de bulunmaktadır. Ayrıca, makalenizi olanaklar dahilinde nasil geliştirebileceğinize ilişkin yapıcı öneriler de bulunmaktadır. Ancak makalenizde metodolojik ve etiğe dair sorunlar olduğu takdirde makale başka bir dergiye gönderilmemelidir. Buna ilaveten başka red nedenleri ise yazının çok uzun olması, yazının okunurken takibinde yaşanan güçlük, yazının ilginç gelmemesi, yerel bir soruna işaret etmesi ve derginin okurlarına ilginç gelmemesi, yazım hataları, içeriğin güncel olmaması, verilerin güncel olmamaları, çalışmanın sınırlılıklarının yeterince açıklanmamış olması, makalenin yeterince iyi yazılmamış olması, beyan ve ifadelerin literatürlerle yeterince desteklenmiş olmamaları, çıkar çatışmasının olması, yazarların katkılarının yeterince açıklanmamış olması, verilerin daha önce kullanılmış olması, yazının başka bir yerde yayınlanmış olması, etik kaygılar, metodolojik kaygılar vb.dir.

\section{Eser Dergiye Kabul Edildikten Sonraki Süreç}

Makaleniz kabul edildikten sonra, dergi içinde üretim aşamasına geçilmektedir. Derginin editörü işini tamamlanmıştır ve artık eserinizi derginin teknik ekibine devretmiştir. Ilk adım, makalenizin derginin mizanpajına uygun olarak yeniden dizilmesidir. ${ }^{13}$ Metin yanı sıra, şekil, tablo ve resimler dergiye uygun biçimde yerleştirilirler. Dizgiden sonra, baskı öncesi yayın taslağı (proof) hazırlanır ve yazarlara son kez okumaları için gönderilir. $\mathrm{Bu}$ süreç bazen haftalar alabilmektedir. Dizgi ekibi, makale ile ilgili anlaşılmayan bazı noktaların aydınlatılmasını isteyebilirler. $\mathrm{Bu}$ aşamaya gelmiş yazılarda, büyük çaplı değişikliklerin yapılması arzu edilmemektedir. Hatta öyle bir zaruret doğacak olursa, oluşacak yeni dizgi masrafları yazarlardan tahsil edilmektedir.

Taslak, yazarlar tarafindan onaylandiktan sonra derginin olanaklarına göre yayına kabul edilmiş makale olarak websitesine yüklenmesi mümkündür. Derginin "first online" uygulaması varsa doğrudan internete de konulabilir. Bu sırada eserinize DOİ (Digital Object Identifier) ataması yapılır ve sonrasında baskı için hazırlık yapılacaktır. Baskı gerçekleştiğinde kalıcı künyesi verilecektir.

Baskıdan sonra, makale artık paylaşılmaya ve atıf almaya hazır olmaktadır. Dergilerin yayın ve telif politikalarına göre yazarların makalelerini medyada paylaşabilmeleri mümkündür. Makale yayınlandıktan sonra, makalede gerçekleşecek olan düzeltmeler sadece derginin sonraki sayılarında basilacak olan "corrigenda", "erratum" ya da "düzeltme" ibareli notları ile mümkün olacaktır.

\section{SONUC}

Araştırma sorusu ve hipotez ile başlayan araştırma süreci, elde edilen bulguların eser olarak yayınlanmasıyla son bulmaktadır. Yapılan araştırmanın, bilimsel ve etik kurallara uyumunun eksiksiz olmasına rağmen, yine de elde edilen bulguların kamuoyu ve akademiya ile paylaşılmasında sorunlar yaşanmaktadır. Hazırlanmış olan bu derleme ile, özellikle eser yayınlama faaliyetlerine yeni başlamış olan meslektaşlarımıza yol göstermek istenmiştir. Eserlerin yayın haline getirilmesi sabır ve sebat gerekmektedir. Bilim yolunda çalışmaya karar vermiş kişilerin, yaşamları boyunca mesailerinin önemli bir kısmını bu faaliyetle geçirmesi beklenmektedir. $\mathrm{Bu}$ çerçevede yazarlar, hem planlamış olduğu çalışmaları sık sık gözden geçirip, araştırmalar konusunda önceliklerini dikkate almalıdır, hem de dergicilik ve yayıncılık alanındaki gelişmeleri takip etmelidirler. Bu çalışmalar, kişisel gelişimimize katkı sağlamaya ve aile hekimliğinin de ülkemizde ve uluslararası düzeyde hak ettiği konuma gelmesini mümkün kılmaya yardımcı olacaktır.

\section{KAYNAKLAR}

1. Wenzel V, Dünser MW, Lindner KH. Wie schreibe ich eine originalarbeit? Eine Anleitung für Einsteiger. Anaesthesist 2007;56(8):828-36.

2. Yaman H, Arı A, İneli B.U, Meşeli F. Kongrede Sunulan Bildiriler İle İlgili Gelecek Planlar1. (Poster) 8. Güz Okulu, 24-28.09.2014, Antalya.

3. Knight LV, Steinbach TA. Selecting an appropriate publication outlet: A comprehensive model of journal selection criteria for researchers in a broad range of 
academic disciplines. International Journal of Doctoral Studies 2008; 3: 59-79.

4. Yaman H, Kara IH. Aile Hekimliği Uzmanlığ Dergilerinin Geleceği ve İndeksler: Çözüm Önerileri. (Editoryal). Konuralp Tıp Dergisi 2014;6(2):1-4

5. Bernard Becker Medical Library. 1. Washington University School of Medicine. Preparıng For Publicatıon: Factors to Consider in Selecting a Journal for Publication. Erişim: https://www.education.umd.edu/HDQM/labs/A lexander/ARL/PubCourse\%20Supplements/Mu rphy\%20\%20Preparing\%20For\%20Publication .pdf. Erişim tarihi: 01.03.2017.

6. Frederic G. Hoppin, Jr. How I Review an Original Scientific Article. American Journal of Respiratory and Critical Care Medicine 2002;166(8):1019-1023.

7. BMC Family Practice. Submission guidelines. Erişisim:

https://bmcfampract.biomedcentral.com/submi ssion-guidelines. Erişim tarihi. 01.03.2017.

8. ICMJE. Preparing for Submission. Erişim: http://www.icmje.org/recommendations/brows e/manuscript-preparation/preparing-forsubmission.html. Erişim tarihi: 01.03.2017.
9. APA. Preparing Manuscripts for Publication in Psychology Journals:

10. A Guide for New Authors. 2010. Erişim: http://www.apa.org/pubs/authors/new-authorguide.pdf . Erişim tarihi: 01.03.2017.

11. Sipahi OR. Makale yayınlama sürecinde dergi seçimi. ANKEM 2011;25 Ek2):229-232.

12. Biyomedikal Dergilere Gönderilen Makalelerde Bulunmas1 Gerekli Standartlar: Biyomedikal Yayınların Yazımı ve Değerlendirilmesi. Ekim 2008'de güncellenmiştir. Çev: Şimşek G, Alicura S, Yılmaz O. Erişim: http://uvt.ulakbim.gov.tr/tip/icmje_08.pdf. Erișim tarihi: 01.03.2017.

13. ICMJE. Defining the Role of Authors and Contributors. Erişim: http://www.icmje.org/recommendations/brows e/roles-and-responsibilities/defining-the-roleof-authors-and-contributors.html . Erişim tarihi: 01.03.2017.

14. Hon F. From submission to sharing: the life cycle of an article. Erişim: https://www.elsevier.com/authorsupdate/story/publishing-tips/life-cycle-of-anarticle. Erişim tarihi: 01.03.2017. 